\title{
IMPLIKASI PUTUSAN MAHKAMAH KONSTITUSI DALAM MENGUJI UNDANG-UNDANG TENTANG JABATAN NOTARIS TERHADAP PENGAWASAN NOTARIS
}

\author{
Oleh: Laurensius Arliman S \\ Dosen Sekolah Tinggi llmu Hukum (STIH) Padang \\ Alamat kantor: JI. AR. Hakim No. 6 Padang \\ Email: laurensiusarliman@gmail.com
}

\begin{abstract}
Abstrak
Salah satu kewenangan MK adalah judicial review yang mengedepankan semangat pembenahan hukum di Indonesia. Judicial review undang-undang yang pernah diajukan para pihak yang berkepentingan ke MK adalah Undang-Undang Jabatan Notaris (UUJN). Judicial review terhadap UUJN ternyata membawa implikasi yang besar terhadap pengaturan jabatan notaris dan juga terhadap politik hukum kenotariatan. Metodologi penelitian yang digunakan dalam penelitian ini adalah penelitian yuridis normatif. Sementara itu, data dalam penelitian ini bersumber dari data sekunder dengan teknik pengumpulan data studi dokumenter. Berdasarkan hasil penelitian dapat diketahui bahwa peraturan notaris telah diuji tiga kali ke MK akibat bertentangan dengan aturan yang lebih tinggi. Implikasi pengujian itu menghapus Pasal 66, dalam perkembangannya terjadi perubahan pada UUJN. Perubahan pada UUJN ternyata juga masih memiliki kelemahan, karena itu perlu dilakukan perbaikan. Penulis menawarkan ide politik hukum kenotariatan yang berkelanjutan di Indonesia, agar memberikan kekokohan bagi notaris di Indonesia.
\end{abstract}

\begin{abstract}
One of the Constitutional Court is a judicial authority which emphasizes the spirit of legal reform in Indonesia. Judicial review of legislation that have been asked the parties concerned to the Court is the Notary Act (UUJN). Judicial review of UUJN it brings major implications for the notary office setting and also to the politics of law notaries. The research methodology used in this research is normative. Meanwhile, the data in this study come from secondary data with data collection documentary studies. Based on the results of this research is that the rules notary has been tested three times to the Court as a result of conflict with the higher rules. The implications of testing was to delete Article 66, in its development, changes in UUJN. Changes to UUJN it also still has a weakness, because it needs to be improved. The author offers a legal political ideas of sustainable notaries in Indonesia, in order to provide robustness to the notary in Indonesia.
\end{abstract}

\section{Kata kunci: MK, Perubahan UUJN, Politik Hukum, Kenotariatan}

\section{Pendahuluan}

Mahkamah Konstitusi (MK) merupakan lembaga yang keberadaannya sangat mempengaruhi ketatanegaraan Indonesia. Pendapat ini didukung dari fakta bahwa beberapa putusan MK telah menciptakan "keguncangan" politik dan ketatanegaraan yang seringkali menjadi dikursus. ${ }^{1}$ MK lahir dari reformasi konstitusi yang mengedepankan semangat pembenahan Indonesia. MK melaju 
menggunakan lokomotif kewenangan konstitusional yang diberikan Undang-Undang Dasar Negara Republik Indonesia Tahun 1945 (UUD 1945). Sebagai salah satu lembaga pemegang kekuasaan kehakiman (selain Mahkamah Agung), MK bertugas melindungi nilai-nilai konstitusi yang seringkali diabaikan oleh penyelengara negara. ${ }^{2}$

MK ditugaskan melindungi publik dari perbuatan legislatif dan eksekutif yang "sembrono" dalam melaksanakan amanah konstitusi. ${ }^{3}$ Selama ini judicial review perundang-undanganlah yang paling banyak diajukan ke MK, dari pada kewenangan MK yang lainnya. Selain judicial review, MK berwenang memutuskan impeachment, sengketa kewenangan antar lembaga negara, sengketa pemilu, dan pembubaran partai politik. ${ }^{4}$ Agaknya, kewenangan MK inilah yang menyebabkan adanya pertentangan dengan berbagai lembaga Negara.

Salah satu judicial review undang-undang yang pernah diajukan ke MK adalah UndangUndang Jabatan Notaris (UUJN). UUJN sendiri merupakan peraturan yang mengatur kode etik notaris dalam menjalankan tugasnya sebagai seorang pejabat. UUJN memberikan pengertian Notaris adalah pejabat umum yang memiliki kewenangan untuk membuat akta otentik dan memiliki kewenangan lainnya sebagaimana dimaksud dalam undang-undang ini atau berdasarkan undang-undang lainnya. ${ }^{5}$ Oleh karena itu, keberadaan lembaga notaris muncul untuk mewujudkan kepastian dan perlindungan hukum bagi anggota masyarakat ${ }^{6}$ melalui akta otentiknya.

Pengaturan tentang jabatan notaris untuk pertama kali diatur melalui Reglement op Het Notarisin Nederlands Indie (stbl.1860:3). Selanjutnya, pada tahun 2004 pengaturan jabatan notaris ditempatkan dalam peraturan perundang-undangan, yakni Undang-Undang Nomor 30 Tahun 2004 tentang Jabatan Notaris (UUJN). Berikutnya pengaturan jabatan notaris disempurnakan lagi dengan Undang-Undang Republik Indonesia Nomor 2 Tahun 2014 tentang Perubahan Atas Undang Undang Nomor 30 Tahun 2004 tentang Jabatan Notaris (Perubahan UUJN), yang telah disahkan pada tanggal 17 Januari tahun 2014 oleh Dewan Perwakilan Rakyat Republik Indonesia (DPR-RI).

Sejak diundangkannya UUJN tanggal 6 Oktober $2004^{7}$ pernah dilakukan dua kali pengujian terhadap UUD 1945 ke MK. Pada dasarnya peraturan perundang-undangan merupakan produk politik. Tidak jarang suatu undang-undang disisipi kepentingan politik atau tidak memenuhi tujuan pembuatannya atau bertentangan dengan aturan yang ada diatasnya sehingga perlu adanya judicial review.

1J.E Sahetapy, Yang Memberi Teladan dan Menjaga Nurani Hukum dan Politik, (Jakarta: Komisi Hukum Nasional RI, 2007), hlm. 357.

${ }^{2}$ Feri Amsari, Pengaruh Putusan Mahkamah Konstitusi Bagi Perkembangan Hukum dan Demokrasi di Indonesia, makalah dalam Seminar Bulanan Hukum Tata Negara Fakultas Hukum Universitas Andalas, (Padang: Universitas Andalas, 1 Februari 2012), hlm. 1.

${ }^{3}$ Charles Simabura, Peran Mahkamah Konstitusi Dalam Mewujudkan Demokrasi Ekonomi (Identifikasi Putusan Pengujian Undang-Undang Terhadap UUD 1945), Jurnal Konstitusi, Volume 2, Nomor 1, September 2013, hlm. 9.

${ }^{4}$ Feri Amsari, Pengaruh Putusan.... Op.Cit., hlm. 2.

${ }^{5}$ Guntur Iskandar, Kekuatan Pembuktian Akta di bawah Tangan yang disahkan dan dibukukan Oleh Notaris, Jurnal Yustisia, Volume, 22, Nomor 1, Juni 2015, hlm. 53.

${ }^{6}$ Zulheriyanto, Pembaharuan Surat Kuasa Membebankan Hak Tanggungan (SKMHT) Dalam Pemasangan Hak Tanggungan, Jurnal Minuta, Volume 1, Nomor 1, Agustus 2013, hlm. 93.

${ }^{7}$ Dalam Lembaran Negara Tahun 2004 Nomor 17, Tambahan Lembaran Negara Nomor 4432. 
Adanya judicial review sangat mempengaruhi peta politik hukum di bidang kenotariatan. Politik hukum kenotariatan terutama terhadap putusan MK dan regulasi-regulasi lain yang mendukung jabatan notaris sangat mempengaruhi jabatan notaris dalam menjalankan jabatannya.

Hal-hal dari putusan MK atas UUJN yang berimplikasi pada politik hukum kenotariatan ini sangat menarik sekali dibahas secara mendalam, karena apabila terdapat undangundang yang bertentangan dengan prinsip kepentingan umum sebagai turunan dari nilainilai konstitusi maka dapat digugat ke MK dengan harapan MK dapat menjaga prinsip demokrasi ekonomi sesuai dengan apa yang menjadi ruh dari UUD 1945. Dalam konteks itu, tulisan ini bermaksud menganalisis secara mendalam apakah akibat judicial review terhadap peraturan jabatan notaris oleh MK selama ini? Bagaimana implikasi keputusan MK bagi perkembangan notaris di Indonesia? Berikutnya bagaimana politik hukum notaris setelah perubahan peraturan UUJN?

\section{Metode Penelitian}

Jenis penelitian ini ialah penelitian hukum normatif atau kepustakaan dengan pendekatan perundang-undangan (statue approach) dan kasus (case approach). Data dalam penelitian ini bersumber dari data sekunder yang terdiri atas bahan hukum primer dan bahan hukum sekunder. Teknik pengumpulan data dengan cara studi dokumenter. Analisis data dilakukan secara kualitaif dan deduktif sebagai metode dalam menarik kesimpulan.

\section{Pembahasan}

\section{Judicial Review Terhadap Peraturan} Jabatan Notaris Oleh Mahkamah Konstitusi

Berikut penulis sajikan hasil judicial review yang pernah diajukan ke MK terhadap UUJN: Pertama, putusan MK Nomor 009-014/PUUIII/2005 perihal Pengujian Undang-Undang Nomor 30 Tahun 2004 tentang Jabatan Notaris.
Perkara ini diajukan oleh Persatuan Notaris Reformasi Indonesia (PERNORI) dalam hal ini bertindak selaku pribadi maupun dalam kedudukannya selaku Ketua Umum, H.M. Ridhwan Indra Romeo Ahadian, dan Himpunan Notaris Indonesia (HNI) dalam hal ini bertindak selaku pribadi maupun dalam kedudukannya selaku Sekretaris Umum Teddy Anwar, yang kemudian disebut Pemohon I. Pemohon I mengajukan permohonan pengujian formal UUJN yang pembentukannya tidak sesuai dengan Undang-Undang Nomor 10 Tahun 2004 tentang Pembentukan Peraturan Perundang-Undangan. Kemudian Pemohon I juga mengajukan pengujian materiil terhadap pasal-pasal dalam UUJN, sebagai berikut:

1. Pasal 1 Ayat (5) dan Pasal 82 Ayat (1) yang dinyatakan bertentangan dengan Pasal 28 E Ayat (3) dan Pasal 28 G (1) UUD 1945.

2. Pasal 67 Ayat (3) huruf b yang dinyatakan bertentangan dengan Pasal 28 D Ayat (1) dan Ayat (2) UUD 1945.

3. Pasal 77 yang dinyatakan bertentangan dengan Pasal 27 Ayat (1) UUD 1945 juncto Pasal 28 G Ayat (1) UUD 1945.

4. Pasal 78 yang dinyatakan bertentangan dengan Pasal 27 Ayat (1) UUD 1945.

Kedua, putusan MK Nomor 014/PUU-III/ 2009. Perkara ini diajukan oleh Hady Evianto, H.M. Ilham Pohan, Ukon Krisnajaya, Yance Budi S.L Tobing, dan H.A. Taufiqurrahman S, yang selanjutnya disebut Pemohon II. Pemohon II juga mengajukan pengujian formal dan pengujian materiil. Dalam permohonan pengujian formal, Pemohon II mendalilkan bahwa pembentukan UUJN bertentangan dengan Pasal 22 AUUD 1945 yang diatur lebih lanjut dalam Undang-Undang Nomor 10 Tahun 2004 tentang Pembentukan Peraturan Perundang-Undangan. Kemudian dalam pengujian materiil, Pemohon II mendalilkan 
bahwa beberapa Pasal dalam UUJN bertentangan dengan UUD 1945, sebagai berikut:

1. Pasal 16 Ayat (1) butir k bertentangan dengan Pasal 36 C Undang-Undang Dasar Negara Republik Indonesia Tahun 1945.

2. Pasal 1 butir 5 juncto Pasal 82 Ayat (1) dalam proses perumusannya dan pelaksanaannya saat ini bertentangan dengan asas / semboyan "Bhinneka Tunggal Ika" juncto ketentuan Pasal 36A juncto Pasal 22A UUD 1945.

Penjelasan terhadap judicial review UUJN perkara Nomor 009/PUU-III/2005. Huruf a, bahwa pemohon mendalilkan bahwa para pemohon mempunyai hak konstitusional yang ditentukan dalam UUD 1945, dalam hal ini antara lain hak yang ditentukan dalam Pasal 28 E Ayat (3) dan Pasal 28 D Ayat (1) UUD 1945. Karenanya, pemohon menganggap hak konstitusional tersebut dirugikan oleh berlakunya UUJN khususnya Pasal 1 angka 5 juncto Pasal 82 Ayat (1) yang merugikan hak kebebasan untuk berserikat, Pasal 15 Ayat (2) huruf $h$ dan huruf $g$ yang merugikan hak atas jaminan kepastian hukum, dan Pasal 67 Ayat (1) sampai dengan Ayat (6) yang merugikan hak untuk mendapat perlakuan yang sama di hadapan hukum. Dalam hal ini, MK menilai bahwa para Pemohon memang memiliki legal standing.

Terhadap pengujian formal, MK menilai suatu undang-undang yang tidak memenuhi persyaratan teknis pembentukan undangundang yang baik (behoorlijke wetgeving) tidak dengan sendirinya secara formal bertentangan dengan UUD 1945. Selanjutnya, terkait dengan perbedaan waktu pengundangan dan pemberlakuan UUJN maka MK berpendapat bahwa hal ini dapat dibenarkan atau dengan kata lain tidaklah salah sebagaimana diatur dalam Pasal 50 Undang-Undang Nomor 10 Tahun 2004 tentang Pembentukan Peraturan
Perundang-Undangan. Namun, terkait dengan dugaan adanya penyuapan dalam pembentukan Undang-Undang tersebut MK tidak berwenang untuk memeriksanya.

Sementara itu, terhadap pengujian materiil Pasal 1 angka 5 UUJN yang didalilkan Pemohon I bahwa ketentuan tersebut bertentangan dengan Pasal 28 E Ayat (3) UUD 1945, MK menyatakan bahwa notaris adalah suatu profesi sekaligus pejabat publik (public official) yang melaksanakan sebagian dari tugas pemerintah. Oleh karena itu, organisasi notaris memang seharusnya merupakan perkumpulan profesi dari para notaris sebagai pejabat umum yang berdiri sendiri di dalam lalu lintas hukum. Akibatnya, adanya persyaratan organisasi notaris harus sebagai badan hukum (rechtspersoon) merupakan sesuatu yang wajar. Dengan demikian, berdasarkan pertimbangan tersebut maka ketentuan yang terkandung dalam Pasal 1 angka 5 UUJN tidak bertentangan dengan UUD 1945. Namun, terhadap Pasal 15 Ayat (2) UUJN MK tidak mempertimbangkannya lebih lanjut karena tidak dimohonkan dalam petitum permohonan.

Huruf b , terhadap Pasal 67 Ayat (1) sampai dengan Ayat (6) UUJN, Pemohon mengkhawatirkan objektivitas perlakuan para notaris yang menjadi anggota Majelis Pengawas terhadap notaris yang mempunyai pertentangan kepentingan dengan notaris yang menjadi anggota Majelis Pengawas. Akan tetapi, MK tidak memiliki pendapat yang sama dengan pemohon. MK menegaskan dalam putusannya bahwa tidak ada relevansinya pasal tersebut untuk dipertentangkan dengan Pasal 28D UUD 1945 dan dalil yang dikemukakan oleh para Pemohon mengenai hal tersebut tidak cukup beralasan karena ketentuan tersebut sama sekali tidak bertentangan dengan hak setiap orang untuk bekerja serta mendapatkan imbalan dan perlakuan yang adil dan layak dalam hubungan kerja. Tambahan pula, menurut MK dalam hal 
ini wajar 3 (tiga) orang dari organisasi notaris untuk menjadi anggota Majelis Pengawas karena notarislah yang paling memahami tugas-tugas dan kewenangan, cara kerja, serta etika yang harus dihormati oleh setiap notaris, sama halnya untuk menjadi notaris tidak bisa dilakukan setiap orang dengan bebas, karena harus memenuhi standar kemampuan dan keahlian tertentu. Dengan demikian, Pasal 67 UUJN tidak bertentangan dengan Pasal 27 Ayat (1) dan Pasal 28 G Ayat (1) UUD 1945.

Huruf $\mathbf{c}$ dan d, menurut MK bahwa Majelis Pengawas merupakan kepanjangan tangan dari Menteri. Dalam rangka pengawasan, wajar jika Majelis Pengawas mendapat pelimpahan sebagian wewenang dari Menteri sebagaimana tercantum dalam Pasal 77 dan Pasal 78 UUJN. Pemberhentian sementara yang dilakukan oleh Majelis Pengawas sambil menunggu Keputusan Menteri atas usul pemberhentian dengan tidak hormat merupakan tindakan yang penting. Pemberhentian sementara dan pengusulan untuk memberhentikan dengan tidak hormat merupakan tindakan tata usaha negara (administratief rechtshandeling). Dengan demikian, kedua Pasal tersebut tidak bertentangan dengan Pasal 27 Ayat (1) dan Pasal 28 G UUD 1945.

Penjelasan terhadap judicial review UUJN dalam perkara Nomor 14/PUU-III/2005. Huruf a, terkait dengan pengujian materiil yang dimohonkan oleh Pemohon II dalam Pasal 16 Ayat (1) huruf k UUJN, Pemohon mendalilkan bahwa ketentuan tersebut bertentangan dengan Pasal 36 A juncto Pasal 36 C UUD 1945. MK berpendapat bahwa ketentuan yang tercantum dalam Pasal 16 huruf $k$ UUJN yang telah mengatur penggunaan lambang negara oleh notaris dalam undang-undang tidak bertentangan dengan maksud yang terkandung dalam Pasal 36 C UUD 1945 sepanjang hal itu digunakan dalam rangka pelaksanaan tugasnya sebagai pejabat umum. Demikian itu, tanpa bermaksud menyatakan bahwa pengaturan sebagaimana termuat dalam Pasal 16 huruf $k$ UUJN sebagai pelaksanaan dari Pasal 36C UUD 1945, MK berpendapat ketentuan demikian tidaklah bertentangan dengan Pasal 36 C UUD 1945 tersebut sehingga dalil Pemohon tidak beralasan.

Huruf b, Para Pemohon juga mendalilkan bahwa Pasal 82 Ayat (1) UUJN bertentangan dengan Pasal 22 A, Pasal 28 E Ayat (3), dan Pasal 28 G Ayat (1) UUD 1945. MK berpendapat bahwa Pasal 82 Ayat (1) UUJN tidak melarang bagi setiap orang yang menjalankan profesi jabatan notaris untuk berkumpul, berserikat dan mengeluarkan pendapat. Namun, dalam hal melaksanakan hak berserikat mereka harus berhimpun dalam satu wadah organisasi notaris karena notaris adalah pejabat umum yang diangkat oleh Negara yang diberi tugas dan wewenang tertentu oleh negara dalam rangka melayani kepentingan masyarakat, yaitu membuat akta otentik.

Dalam UUJN memang tidak disebut Ikatan Notaris Indonesia (INI) sebagai organisasi tunggal yang mewadahi notaris. Namun, jika dalam kenyataannya pemerintah menetapkan INI sebagai wadah tunggal organisasi notaris sebagaimana dimaksud oleh Pasal 82 Ayat (1) UUJN sesungguhnya ketentuan ini tidak berada pada tataran normatif undang-undang melainkan pada tataran pelaksanaan undangundang. Oleh karenanya, tidak menyangkut persoalan konstitusionalitas. Sebaliknya, jika para Pemohon tidak puas terhadap keputusan atau pengaturan lebih lanjut sebagai pelaksanaan undang-undang tersebut maka para Pemohon dapat melakukan upaya hukum, tetapi bukan kepada MK.

Berdasarkan pertimbangan-pertimbangan di atas maka baik dalil Pemohon Perkara 009/PUU-III/2005 maupun Pemohon Perkara 014/PUUIII/2005 tidak cukup beralasan sehingga permohonan para Pemohon harus ditolak. Putusan ini mengacu pada Pasal 56 Ayat 
(5), Undang-Undang Republik Indonesia Nomor 24 Tahun 2003 tentang Mahkamah Konstitusi. $^{8}$

Ketiga, Putusan MK Nomor 49/PUU-X/ 2012. Kant Kamal, lewat kuasa hukumnya Tomson Situmeang dan kawan kawan, yang merasa dirugikan hak konstitusinya terkait laporan pemalsuan akta otentik berupa Surat Jual Beli Saham oleh notaris di Cianjur. Terkait adanya dugaan terhadap kasus hukum yang dilakukan oleh seorang notaris ${ }^{9}$ maka dalam pemanggilan notaris di dalam Pasal 66 Ayat (1) UUJN dalam rangka penegakan hukum menyebutkan bahwa penyidik, penuntut umum atau hakim dalam hal pengambilan minuta akta serta pemanggilan notaris harus dengan persetujuan Majelis Pengawas Daerah (MPD).

Terhadap Putusan MK yang diajukan oleh Kant Kamal yang diputus pada tanggal 23 Maret 2013 dengan putusan Nomor 49/PUU-X/2012 telah memutuskan: mengabulkan permohonan Pemohon untuk seluruhnya atas pertimbangan:

a. Menyatakan frasa dengan persetujuan MPD dalam Pasal 66 Ayat (1) UUJN bertentangan dengan UUD 1945.

b. Menyatakan frasa dengan persetujuan MPD dalam Pasal 66 Ayat (1) UUJN tidak mempunyai kekuatan hukum mengikat.

Berkaitan dengan putusan tersebut yang menjadi pertanyaan apakah frasa dengan persetujuan MPD dalam Pasal 66 UUJN tersebut dianggap tidak ada? Tidak tertulis atau frasa tersebut tetap dianggap ada? Namun, bertentangan dengan UUD 1945 sehingga tidak mempunyai kekuatan hukum mengikat.
Dalam hal ini penulis berpendapat bahwa bila frasa dengan persetujuan MPD dianggap tidak ada atau dianggap tidak tertulis maka notaris tetap wajib memenuhi pemanggilan oleh penyidik, penuntut umum atau hakim sebagaimana dimaksud dalam Pasal 66 Ayat (1) UUJN. Jika demikian, notaris yang semula dapat menolak untuk dipanggil sebelum adanya persetujuan MPD kini tidak lagi dapat menolak untuk hadir karena hal itu menjadi kewajiban yang diatur dalam UUJN.

Senada dengan hal di atas, meskipun jika frasa tersebut tetap dianggap ada, padahal frasa tersebut dinyatakan bertentangan dengan UUD 1945 dan tidak mempunyai kekuatan hukum mengikat, tetap saja prosedur pemanggilan notaris harus dilakukan melalui MPD selaku pengawas notaris. Sehubungan dengan pemanggilan notaris, hendaknya segera dikeluarkan peraturan Menteri Hukum dan HAM agar tidak terjadi kesemena-menaan dalam pemanggilan notaris. ${ }^{10}$

Dalam pertimbangan MK guna memutuskan perkara beberapa alasan melandasi putusan ini, yakni adanya prinsip persamaan di depan hukum (equality before the law) yang terkandung dalam Pasal 28 Ayat (1) UUD 1945 yang berlaku universal dan juga terkandung pada Article 26 ICCPR (International Covenant on Civiland Political Rights) tahun 1966 yang juga sudah diratifikasi oleh Indonesia melalui Undang-Undang Nomor 12 Tahun 2005. Selanjutnya, MK berpendapat bahwa prinsip demokrasi dan "rule of law" dapat dicederai dengan frasa di atas, yaitu kekuasaan kehakiman yang merdeka (Independence of the Judiciary) yang harus dikawal oleh MK dan MA. Campur tangan MPD juga dianggap dapat

${ }^{8}$ Musri Nauli, Pandangan Konstitusi Terhadap Notaris (Studi Kasus Putusan MK Terhadap Notaris), Jurnal Kenotariatan Universitas Jambi, 2014, hlm. 25.

${ }^{9}$ Rahmad Hendra, Tanggung Jawab Notaris Terhadap Akta Otentik yang Penghadapnya Mempergunakan Identitas Palsu di Kota Pekanbaru, Jurnal IImu Hukum, Volume 3, Nomor 1, hlm. 56.

${ }^{10}$ Alwesius, di dalam Laurensius Arliman S, Notaris dan Penegakan Hukum oleh Hakim, (Jogjakarta: Budi Mulia, 2015), hlm.78. 
menimbulkan penundaan proses peradilan dan keadilan. Secara konseptual dapat dikatakan tidak hanya "justice delayed justice denied", tetapi penundaan keadilan juga melanggar Hak Asasi Manusia (delay of justice is violation of human rights). Perkecualian tentu saja dimungkinkan terhadap kedudukan notaris sepanjang berkaitan dengan Kode Etik Notaris yang bersentuhan dengan sikap, tingkah laku dan moralitas serta kehormatan (dignity) notaris, bukan dalam penegakan hukum, khususnya sistem peradilan pidana (criminal justice system). ${ }^{11}$ Gangguan terhadap kekuasaan kehakiman yang merdeka yang bersifat universal bahkan bisa menimbulkan ketidak-adilan (criminal injustice system). Dalam persidangan dan hukum acara tersebut, putusan dari MK tentu diartikan bahwa putusan ini final dan mengikat (final and binding).

\section{Implikasi Putusan Mahkamah Konstitusi dan Perubahan Undang Undang Jabatan Notaris Terhadap Pengawasan Notaris}

Dari tiga judicial review UUJN ke MK yang diajukan oleh para pihak, hanya satu dikabulkan oleh MK, yakni putusan MK Nomor 49/PUU-XI 2012 yang mengabulkan permohonan Pemohon untuk seluruhnya sehingga Pasal 66 Ayat (1) UUJN tidak mempunyai kekuatan hukum mengikat atau dengan kata lain dihapus. Keputusan MK ini berimplikasi pada pengawasan notaris dalam melakukan tugasnya sebagai pejabat notaris. ${ }^{12}$

Dapat diketahui lingkup pengawasan notaris berdasarkan Pasal 67 Ayat (5) UUJN meliputi pengawasan terhadap perilaku notaris dan jabatan notaris. Majelis Pengawas Notaris sendiri merupakan organisasi pengawas yang terletak di kabupaten atau kota di setiap provinsi yang ada di wilayah Indonesia. Sebelum berlakunya UUJN, pengawasan, pemeriksaan dan penjatuhan sanksi terhadap notaris dilakukan oleh badan peradilan. Sebelum adanya Pasal 66 UUJN, pengawasan notaris pernah diatur di dalam: ${ }^{13}$

“a. Pasal 140 Reglement op de Rechtelijke Organisatie en Het Der Justitie (Stbl. 1847 No. 23), Pasal 96 Reglement Buitengewesten, Pasal 3 Ordonantie Buitengerechetelijke Verihtingen -Lembaran Negara 1946 No.135, dan Pasal 50 PJN.

b. Peradilan Umum dan Mahkamah Agung sebagaimana diatur dalam Pasal 32 dan 54 Undang-undang Nomor 13 Tahun 1965 tentang Pengadilan dalam Lingkungan Peradilan Umum dan Mahkamah Agung.

c. Surat Edaran Mahkamah Agung Republik Indonesia Nomor 2 Tahun 1984 tentang Cara Pengawasan Terhadap Notaris, keputusan bersama Ketua Mahkamah Agung dan Menteri Kehakiman Nomor KMA/006/SKB/VII/ 1987 tentang Tata Cara Pengawasan, Penindakan dan Pembelaan Diri Notaris.

d. Pasal 54 Undang-Undang Nomor 8 Tahun 2004".

Dengan dihapusnya Pasal 66 maka pasal ini tidak dapat digunakan lagi sebagai

${ }^{11}$ Diah Sulistyani, di dalam Ibid, hlm. 80.

${ }^{12}$ Unan Pribadi, Tinjauan Kritis Tentang Pengaturan Kembali Substansi Ketentuan Pasal 66 Ayat (1) Undang-Undang Nomor 30 Tahun 2004 tentang Jabatan Notaris yang Sudah Dinyatakan Tidak Mempunyai Kekuatan Hukum Mengikat oleh Mahkamah Konstitusi, Jurnal Legislasi Indonesia, Volume 11, Nomor 2, Juni 2014, hlm.135.

${ }^{13}$ Habib Adjie, Majelis Pengawas Notaris Sebagai Pejabat Tata Usaha Negara, (Bandung: Reflika Aditama, 2011), hlm.1. 
hak lembaga MPD dalam menjalankan kewenangannya di daerah. ${ }^{14}$ Namun, putusan MK ini tidak serta merta menghilangkan eksistensi MPD. Dalam beberapa pasal pada UUJN masih tergambar jelas eksistensi MPD antara lain:

a. Pasal 58, MPD membubuhkan parafnya pada setiap setiap halaman pada daftar akta, daftar surat di bawah tangan yang disahkan, daftar surat di bawah tangan yang dibukukan, dan daftar surat lain yang merupakan kewajiban notaris untuk membuatnya.

b. Pasal 69 yang menyatakan bahwa Kedudukan atau keberadaan MPD masih ada di daerah sebagai Lembaga Pengawas di daerah.

c. Pasal 70 terhadap kewenangan MPD untuk menerima laporan dan menyelenggarakan sidang untuk pemeriksa atas adanya dugaan pelanggaran Kode Etik Notaris, pelanggaran pelaksanaan jabatan notaris dan pelaggaran undang-undang yang dilakukan notaris, melakukan pemeriksaan terhadap protokol notaris secara berkala, memberikan izin cuti kepada notaris, menetapkan notaris pengganti, menentukan tempat penyimpanan protokol notaris, menunjuk notaris yang akan bertindak sebagai pemegang sementara protokol notaris, dan membuat dan menyampaikan laporan sebagaimana dimaksud pada huruf a, huruf $b$, huruf $c$, huruf $d$, huruf e, huruf $f$, dan huruf $g$ kepada Majelis Pengawas Wilayah (MPW).

d. Pasal 71, MPD melakukan pemeriksaan terhadap protokol notaris dan membubuhi parafnya, membuat berita acara pemeriksaan dan menyampaikannya kepada MPW setempat, notaris yang bersangkutan, Organisasi Notaris, dan Majelis Pengawas Pusat (MPP), menerima salinan yang telah disahkan dari daftar akta dan daftar lain dari notaris dan merahasiakannya, memeriksa laporan masyarakat terhadap notaris dan menyampaikan hasil pemeriksaan tersebut kepada MPW dalam waktu 30 (tiga puluh) hari, dengan tembusan kepada pihak yang melaporkan, notaris yang bersangkutan, MPP, dan organisasi notaris, dan menyampaikan permohonan banding terhadap keputusan penolakan cuti.

Kewenangan MPD juga diatur dalam Peraturan Menteri Hukum dan Hak Asasi Manusia Republik Indonesia Nomor M.02. PR.08.10 Tahun 2004. Implikasi dari putusan MK ini kemudian menjadi latar belakang dilakukannya perubahan UUJN. Dalam rapat Koordinasi Majelis Pengawas Notaris (MPN) yang dilangsungkan di Bandung akhir Oktober tahun 2013, menghasilkan rekomendasi yang utamanya menyangkut penguatan kelembagaan MPN. Khususnya berkaitan dengan dihilangkannya Pasal 66 Ayat (1) UUJN oleh Putusan MK. ${ }^{15}$ Akibat penghilangan persetujuan MPD, sedikit banyak akan menganggu kenyamanan para notaris dalam rangka menjalankan tugas dan jabatan yang selama ini mendapatkan perhatian serta perlindungan MPN. ${ }^{16}$ Oleh karenanya, dalam rapat tersebut salah satu pembahasan adalah mengenai hasil putusan MK tersebut.

\footnotetext{
${ }^{14}$ Aryani Witasari, MPD Buka Advokat Para Notaris Berdasarkan Undang-Undang No. 30 Tahun 2004 tentang Jabatan Notaris, Jurnal Hukum, Volume XXVII, Nomor 2, Desember 2012, hIm. 898.

${ }^{15}$ Nur Ichwan, Direkomendasikan Perlu Ada Pengganti Pasal 66, Majalah Renvoi, Edisi November 2013, hlm. 39.

${ }^{16}$ Andy Supratno dan Maroloan J. Baringbing, Putusan MK Jadi Topik Bahasan Dalam Rakor MPN, Majalah Renvoi, Edisi November, 2013, hlm. 40.
} 
Visi dalam meyelenggarakan rapat koordinasi MPN untuk mengoptimalkan fungsi dan peranan majelis pengawas pasca keputusan dari MK. Menteri Hukum dan Hak Asasi Manusia maupun dari Ketua Majelis Pusat Pengawas Notaris (MPPN) mempunyai semangat yang tinggi untuk melakukan pembinaan dan pengawasan terhadap notaris dalam kaitan meningkatkan profesionalitas dalam menjalankan tugas dan jabatan. Tambahan pula, dalam Rakornas ini terkandung maksud dari pihak Kemenkumham untuk memperhatikan hal yang selama ini mungkin kurang mendapatkan perhatian, seperti hal-hal yang menyangkut sarana dan prasarana penunjang MPD. Sebagai ujung tombak MPN, hal itu sangat diharapkan oleh MPD untuk melaksanakan tugas pembinaan dan pengawasan notaris. Dalam rapat itu ditetapkan dan diputuskan oleh tim perumus yang diketuai oleh Bambang Rantam Sariwanto, Bardar Baraba, Abdul Bari Azed, Aidir Awin Daud, Widodod Suryandono, Isyana W.Sadrajarwo, M.J Barimbing, Nur Ichwan, Nur Ali, Sri Yusfini Yusuf, dan Nunung Suryati.

Pasca keputusan MK Nomor 49/PUU-XI 2012 mendorong Pengurus Pusat INI untuk terus melakukan usaha dalam penjagaan kerahasiaan akta yang dibuat oleh notaris, antara lain penandatangan MOU dengan Kapolri perihal tata cara pemanggilan notaris berkaitan dengan keterangan akta dan dengan stake holder lainnya seperti Kemenkumham hingga pada akhirnya Tim Perumus RUUJN mendapat masukkan dengan pembentukkan Majelis Kehormatan Notaris (MKN) dalam rangka mengatur mekanisme pemeriksaan Notaris berkaitan dengan akta otentik yang dibuatnya. ${ }^{17}$

Munculnya MKN dalam rumusan RUUJN untuk menjawab kegelisahan para notaris dalam menyikapi tata cara pemanggilan notaris oleh penegak hukum, polisi, hakim dan jaksa. Majelis Kehormatan Notaris (MKN) yang merupakan pintu masuk izin penegak hukum untuk memanggil dan memeriksa notaris. Tata cara pemanggilan yang sebenarnya telah dianulir oleh MK melalui putusannya muncul kembali dalam wajah baru bernama Majelis Kehormatan Notaris (MKN). Apabila RUUJN ini disahkan maka penegak hukum, polisi, hakim dan jaksa, kembali harus minta izin organisasi untuk memeriksa atau memanggil notaris untuk diminta keterangan. ${ }^{18}$ Pada tanggal 17 Desember 2013 RUUJN disahkan oleh DPR.

Hanya saja ada kelemahan dalam RUUJN ini, yaitu di dalam RUU tidak disebutkan apa yang dimaksud dengan Majelis Kehormatan, seperti Pasal 1 menjelaskan lembaga-lembaga lainnya antara lain Majelis Pengawas. ${ }^{19}$ Ketiadaan definisi ini merupakan suatu kealpaan dari para perumus RUUJN sehingga seolah-olah lembaga baru ini hanya merupakan suatu lembaga tempelan belaka. Menurut Alwesius pasal tersebut tidak mengatur kewenangan apa yang dimiliki oleh MKN. Akibatnya, sangat sulit bagi MKN untuk menjalankan tugasnya kelak yang diatur berdasarkan Peraturan Menteri. ${ }^{20}$

Pada tanggal 17 Januari 2014 perubahan UUJN diundangkan dengan Undang-Undang

\footnotetext{
${ }^{17}$ Syafran Sofyan, PP INI Lakukan Sosialisasi Menyeluruh-Empat Pasal Krusial UUJN Perubahan Harus Dipahami, Majalah Renvoi, Edisi Februari, 2014, hlm. 27.

${ }^{18}$ Media Notaris, RUU Perubahan UU Jabatan Notaris Disetujui - Ijin Memeriksa Notaris Muncul Lagi, http://medianotaris.com/ruu_perubahan_uu_jabatan_notaris_disetujui_berita346.html, diunduh 23 September 2015.

${ }^{19}$ Alwesius, di dalam Laurensius Arliman S, Notaris dan Penegakan...Op.Cit., hlm.101.

${ }^{20} / \mathrm{bid}$.
} 
Nomor 2 Tahun 2014 tentang Perubahan Undang-Undang Nomor 30 Tahun 2004 tentang Undang-Undang Jabatan Notaris. Selain kelemahan tidak adanya definisi Majelis Kehomatan Notaris pada pasal awal perubahan UUJN. Selanjutnya, ditemukan pula pasal-pasal yang tumpang tindih antara Majelis Kehormatan dengan MPN. Jika dilihat dalam pasal-pasalnya ada yang menyebutkan itu kewenangan Majelis Kehormatan, tetapi di pasal lain menjadi kewenangan MPN. Kewenangan ini seharusnya diperjelas agar tidak ada ada tumpang tindih kewenangan. ${ }^{21}$

Kehadiran MKN ini sebaiknya berjenjang, baik dari tingkat daerah, tingkat wilayah, tingkat pusat. Demikian itu, agar kedepannya pengawasan terhadap notaris dapat dilakukan lebih baik dan transparan. Hal ini senada dengan pendapat Zukkifli Harahap yang menyebutkan bahwa dalam pembentukkan Lembaga MKN seharusnya berjenjang, tidak hanya ditingkat provinsi saja, tetapi juga di tingkat daerah. Kalau nanti hanya dibentuk satu di tingkat provinsi, misalkan dengan jumlah notaris DKI Jakarta yang sudah mencapai 1000 notaris maka mereka yang duduk sebagai anggota MKN tidak akan bisa bekerja sebagai notaris. Hal ini dimungkinkan karena relatif banyak notaris yang dipanggil pihak kepolisian dalam setiap minggu. ${ }^{22}$

Beberapa sosialisasi terhadap UU Nomor 2 Tahun 2014 tersebut, telah banyak menimbulkan aksi dan reaksi dari para notaris, para klien atau masyarakat yang di dalam tahap sosialisasi sudah memasuki tahap law behaviour (sikap atau perilaku yang merupakan akibat dari dikeluarkannya perubahan UUJN). Ada sikap yang mendukung sepenuhnya dan ada sikap yang mendukung. Namun, masih bingung terhadap pelaksanaan beberapa pasal dalam perubahan UUJN tersebut, karena di dalam penjelasan perubahan UUJN tersebut dinyatakan "Cukup Jelas". Namun, ternyata dalam praktik pelaksanaannya "Belum Jelas" sehingga timbul ketidakseragaman di lapangan, akhirnya menimbulkan reaksi dan aksi. ${ }^{23}$

Direktur Jenderal Administrasi Hukum Umum (AHU) Kementerian Hukum dan Hak Asasi Manusia Republik Indonesia, Aidir Amin Daud juga menegaskan bahwa masih banyak oknum notaris yang tidak teliti dalam melakukan verifikasi data pemohon akta. Akibatnya, hampir setiap hari Kemenkumham selalu menerima laporan dan menghadapi gugatan. Karena itu, Aidir Amin Daud meminta agar ke depan notaris harus lebih ketat dan tidak serampangan dalam menjalankan tugas. ${ }^{24}$

Setelah keluarnya perubahan UUJN diharapkan secepatnya akan keluar Peraturan Pemerintah tentang MKN ini agar dapat segera dilaksanakan. Melalui peraturan yang jelas maka dapat memberikan kepastian hukum, dan ketenangan dalam menjalankan profesinya seperti amanah undang-undang.

\section{Gagasan Politik Hukum Kenotariatan Terhadap Jabatan Notaris Pasca Perubahan Undang Undang Jabatan Notaris \\ Gagasan politik hukum kenotariatan sangat dibutuhkan di dalam dunia kenotariatan,} hlm. 7.

${ }^{21}$ Zukkifli Harahap, Majelis Kehormatan Idealnya Berjenjang, Majalah Renvoi, Edisi Februari, 2014,

${ }^{22}$ Ibid.

${ }^{23}$ Diah Sulistyani RS, http://medianotaris.com/ kajian_uu_jabatan_notaris_perubahan_berita363.html, "Kajian Beberapa Pasal dalam UU Nomor 2 tahun 2014 tentang Perubahan UU Jabatan Notaris Nomor 30 tahun 2004", diunduh 22 September 2015.

${ }^{24} \mathrm{http}: / /$ sulsel.kemenkumham.go.id/berita/berita-utama/554-sosialisasi-perubahan uu-no-30-2004tentang-jabatangdx-notaris-dan-sistem-pelayanan-publik-secara-online. Diunduh 23 September 2015. 
terutama pasca perubahan UUJN, mengingat adanya aturan yang hadir pasca perubahan undang-undang tersebut. Perubahan UUJN sendiri merupakan politik hukum di dalam kenotariatan, karena ada berapa pasal di dalam UUJN tidak ada di dalam pasal penjelasan. Salah satu contoh, yakni Pasal 66.

Paket undang-undang dalam bidang politik dapat dijadikan salah satu tolak ukur untuk melihat bangunan sistem kelembagaan negara yang dipakai. ${ }^{25}$ Pengaruh politik dalam pembentukan hukum tampak jelas pada pembentukan peraturan perundang-undangan. Tiap tahapan pembentukan peraturan perundang-undangan tidak dapat terelakkan dari pengaruh politik, yang akhirnya berdampak pada substansi peraturan perundang-undangan yang dibentuk oleh pemerintah. ${ }^{26}$

Suatu peraturan perundang-undangan dibentuk guna mencapai tujuan hukum. Tujuan hukum itu antara lain kepastian, kemanfaatan dan keadilan yang akan berujung pada ketertiban. Namun, Peter Mahmud Marzuki berpendapat bahwa hukum juga harus dapat menciptakan damai sejahtera bukan hanya saja ketertiban. Damai sejahtera inilah yang merupakan inti dari tujuan hukum. Dalam situasi damai sejahtera hukum melindungi kepentingan manusia baik secara materil maupun immaterial dari perbuatan yang merugikan. ${ }^{27}$ Tujuan hukum ini juga yang ingin dicapai oleh peraturan dalam bidang kenotariatan. Dalam rangka mencapai tujuan hukum tersebut maka beberapa pengaturan yang menyangkut notaris dicabut dan dinyatakan tidak berlakui. ${ }^{28}$

Dalam pelaksanaannya pembaharuan UUJN ini memang belum bisa menghilangkan kekhawatiran notaris dalam menjalankan tugasnya sebagai pejabat publik. Notaris dalam menjalankan tugasnya sewaktu-waktu dapat digugat oleh para pihak, bahkan ada kemungkinan mendapat tuntutan secara pidana. ${ }^{29}$

Kelemahan pada pembaharuan UUJN seharusnya tidak terjadi bilamana telah dipersiapkan dan disusun oleh pihak yang memang berkompeten seluruhnya pada dunia notariat. Di dalam perubahan UUJN yang diundangkan di tahun 2014, substansi atau materinya disusun dan dipersiapkan oleh pihak yang berada di luar pihak pelaku notariat, yang tidak mustahil mempunyai pandangan atau persepsi yang berbeda dengan pandangan notaris dalam beberapa masalah kenotariatan. ${ }^{30}$ Terhadap perubahan UUJN ada beberapa gagasan politik hukum terhadap kata atau kalimat yang perlu dipahami maknanya: ${ }^{31}$

"1. Fungsi dari MPN yang mempunyai kewenangan dan kewajiban untuk melaksanakan pembinaan dan pengawasan terhadap Notaris. Pasal 66 tentang MKN diadakan dalam rangka pembinaan notaris. Hal ini patut dipertanyakan apakah benar ketentuan

\footnotetext{
${ }^{25}$ Yuliandri, Membentuk Undang-Undang Berkelanjutan, Jurnal Konstitusi, Volume II, Nomor 2, November 2009, hlm. 10.

${ }^{26}$ Delfina Gusman, Problematikan Dalam Pembentukan Peraturan Perundang-Undangan di Indonesia, Jurnal Yustisia, Volume 19, Nomor 1, 2012, hlm.17.

${ }^{27}$ Peter Mahmud Marzuki, Pengantar Ilmu Hukum, Cetakan Kedua (Jakarta: Kencana, , 2009), hlm.149.

${ }^{28}$ Abdul Ghofur Anshori, Lembaga Kenotariatan Indonesia Perspektif Hukum dan Etika, (Yogyakarta: Ull Pers, 2009), hlm. 182.

${ }^{29}$ Ibid, hlm. 183.

${ }^{30}$ A. Partomuan Pohan, Beberapa Catatan Atas UU No.2/2014 tentang Perubahan Atas UU No.30/2004 tentang Jabatan Notaris, makalah yang disampaikan pada Sosialisasi Undang-Undang Nomor 2 Tahun 2014 tentang Perubahan Undang-Undang Nomor 30 Tahun 2004 tentang Jabatan Notaris, Padang, 14 Januari 2014, hlm. 4.

${ }^{31}$ Ibid, hlm. 7-21.
} 
Pasal 1 butir 6 tentang MPN berfungsi melaksanakan pembinaan dan pengawasan terhadap notaris? Oleh sebab itu, terdapat 2 (dua) majelis yang bertugas melaksanakan pembinaan terhadap notaris, yaitu MPN dan MKN. Bilamana merujuk pada Pasal 67 fungsi MPN adalah melaksanakan pengawasan terhadap notaris (tanpa disebut adanya fungsi pembinaan). Berkaitan dengan ini, tidak seharusnya fungsi dari MPN fokus kepada pengawasan notaris saja, dan pembinaan diserahkan kepada MKN.

2. Terhadap frasa dan bentuk kutipan akta. Bila kita artikan kutipan akta adalah kutipan kata demi kata dari satu atau beberapa bagian dari akta dan pada bagian bawah kutipan akta tercantum frasa "diberikan kutipan". Kata pengambil alihan itu selaras dengan makna kutipan akta yang terdapat dalam Pasal 1 butir 10, yaitu adalah kutipan kata demi kata dari satu atau beberapa bagian dari akta, berarti kalimat atau bagian yang dikutip harus sama bunyinya dengan bagian dari akta yang dikutip. Dengan demikian, frasa bagian bawah kutipan akta yang dalam Pasal 1 butir 10 disebut sebagai "diberikan sebagi kutipan" makna sesungguhnya harus diartikan sebagai "diberikan sebagai kutipan yang sama bunyinya" atau lebih lengkap lagi dapat dimaknai sebagai "diberikan sebagai kutipan yang kata demi kata sama bunyinya" (sebagaimana termuat dalam Pasal 38 Ayat (4) Stbl 1860 No.3). Selain bunyi frasa bagian akhir tersebut perlu pula dipahami dan disepakati bersama bagaimana bentuk atau format kutipan tersebut. Mungkin bisa melihat praktik semasa dan berdasarkan Notaris Reglement, yang menentukan bahwa dalam kutipan akta selain memuat bagian akta yang dikutip, juga harus dimuat: kepala dan penutup akta, tentang para penghadap dan jabatan atau kedudukannya, serta tentang tanda tangan para penghadap, para saksi dan notaris.

3. Notaris sebagai pejabat umum satusatunya yang berwenang membuat akta otentik. Dalam Pasal 15 Ayat (1) memberikan konsekuensi harus ada tambahan kata (seperti pada PJN yang adanya kata-kata pejabat umum satu-satunya), jika tidak ada tambahan kata tersebut, sub kalimat Pasal 15 Ayat (1) akan kehilangan makna atau mempunyai makna yang berbeda. Jika dilihat Pasal 15 Ayat (1) berbunyi sebagai berikut: Notaris berwenang membuat akta autentik mengenai semua perbuatan, perjanjian, dan penetapan yang diharuskan oleh peraturan perundang-undangan dan/ atau yang dikehendaki oleh yang berkepentingan untuk dinyatakan dalam akta autentik, menjamin kepastian tanggal pembuatan akta, menyimpan akta, memberikan grosse, salinan dan kutipan akta, semuanya itu sepanjang pembuatan akta itu tidak juga ditugaskan atau dikecualikan kepada pejabat lain atau orang lain yang ditetapkan oleh undang-undang. Harusnya lebih ada penegasan lagi sebagai berikut: Notaris pejabat umum satu-satunya yang berwenang membuat akta autentik mengenai semua perbuatan, perjanjian, dan penetapan yang diharuskan oleh peraturan perundang-undangan dan/ atau yang dikehendaki oleh yang berkepentingan untuk dinyatakan dalam akta autentik, menjamin 
kepastian tanggal pembuatan akta, menyimpan akta, memberikan grosse, salinan dan kutipan akta, semuanya itu sepanjang pembuatan akta itu tidak juga ditugaskan atau dikecualikan kepada pejabat lain atau orang lain yang ditetapkan oleh undang-undang.

4. Mengenai groose akta, sesuai ketentuan Pasal 1 butir 11 UUJN, menyatakan bahwa grosse akta adalah salah satu salinan akta untuk pengakuan utang dengan kepala akta "Demi Keadilan Berdasarkan Ketuhanan Yang Maha Esa", yang mempunyai kekuatan eksekutorial. Perkataan salah satu salinan akta, rasanya perlu diluruskan oleh karena dikenal adanya grosse I, groose II, grosse III dan selanjutnya. Seharusnya salinan akta "untuk pengakuan utang" juga perlu mendapatkan penegasan karena groose akta dapat dikeluarkan untuk akta yang dibuat dalam minuta dan yang dapat dikeluarkan untuk akta yang dibuat dalam minuta dan yang dapat dikeluarkan salinannya, sedangkan groose akta yang mempunyai kekuatan eksekutorial adalah akta yang memuat atau menyatakan adanya kewajiban untuk melakukan suatu prestasi yang dapat dinilai dengan uang. ${ }^{32}$

5. Di dalam akta notaris sering diperlukan rujukan pada pasal atau ayat lain, sebagaimana hal tersebut sering ditemukan dalam teks undangundang. Di dalam kedua hal tersebut dituntut adanya ketelitian dalam melakukan rujukan (cross-reference). Misalnya saja Pasal 9, diubah dengan menambahkan satu sub-ayat baru, yang menjadi butir e (baru) dari Pasal 9 Ayat (1). Harusnya terhadap hal ini harus ketelitian dan ketegasan, agar tidak terjadi ketimpangan makna nantinya. Selanjutnya Pasal 10 tidak mengalami perubahan (atau tetap). Namun, Pasal 10 tersebut sesungguhnya mengatur kelanjutan dari "pemberhentian sementara" yang dimuat dalam Pasal 9 Ayat (1) tetapi karena Pasal 10 tidak mengalami perubahan maka terjadi kekosongan aturan, yaitu Pasal 10 belum mengatur kelanjutan dari apa yang diatur dalam butir tambahan Pasal 9 Ayat (1) butir e tersebut, yaitu tentang bagaimana kelanjutan dari notaris yang telah diberhentikan sementara akibat dari adanya penahanan oleh yang berwenang terhadap notaris sehingga tidak jelas karena tidak ada atau belum ada ketentuannya. Notaris yang mengalami penahanan tersebut dapat diangkat kembali. Diangkat kembali setelah haknya dipulihkan (sebagaimana diatur Pasal 10 ayat (1)), atau setelah pemberhentian sementara berakhir (sebagaimana dimaksud Pasal 10 ayat (2)).

Selain adanya pembahasan dan gagasan politik hukum terhadap beberapa kata atau kalimat yang perlu dipahami maknanya, seperti yang telah dijelaskan di atas maka dalam perubahan UUJN ini juga harus mencermati beberapa ketentuan kabur, antara lain: ${ }^{33}$

\footnotetext{
${ }^{32} \mathrm{Hal}$ ini merupakan kesimpulan dari Seminar Nasional tentang Groose Akta yang diadakan oleh Ikatan Notaris Indonesia di Surabaya pada tanggal 24-25 September 1986, dengan pembicara utama adalah Hakim Agung Asikin Kusumaatmadja.

${ }^{33}$ Ibid, hlm. 22-36.
} 
1. Ketentuan sidik jari seperti yang disebutkan pada Pasal 16 Ayat (1) butir c, bahwa melekatkan surat dan dokumen serta sidik jari penghadap pada minuta akta. Memaknai hal ini banyak notaris akan terkejut dan mempertanyakan makna sub ayat ini, serta manfaat apa yang hendak dicapai dengan ketentuan ini dan apakah mungkin akan tercapai. Walaupun pasal ini mengandung beberapa kekaburan, namun jika mau bersikap positif terhadap aturan yang sudah menjadi undang-undang, mungkin dapat disepakati beberapa hal berkenaan ketentuan sub ayat tersebut (ketentuan Ayat (1) butir c). Ketentuan Ayat (1) butir c tersebut mewajibkan dilekatkannya pada minuta akta, surat dan dokumen serta sidik jari para penghadap, sidik jari dimaksud dibubuhkan pada sehelai kertas, yang kemudian dilekatkan pada minuta, surat dan dokumen penghadap, adalah surat dokumen jati diri dari segenap para penghadap, dalam bentuk foto copy kartu tanda penduduk, passport, surat izin mengemudi, atau lainnya, yang harus dilekatkan pada minuta akta, penghadap yang dimaksud dalam ketentuan Ayat (1) butir c ini, adalah semua penghadap baik yang dapat membubuhkan tanda tangannya maupun yang tidak dapat membubuhkan tanda tangannya (baik karena buta atapun karena sebab lainnya), sesuai dengan ketentuan tata bahasa baku untuk legal drafting (Undang-Undang No. 12 Tahun 2011 tentang Pembentukan Peraturan Perundang-undangan) kata dalam arti majemuk tidak perlu ditulis dalam bentuk kata majemuk (kata ulang), karena suatu kata dapat berarti tunggal atau mejemuk sesuai dengan konteks kalimatnya, menurut penjelasan pihak pemerintah, tujuan dari ketentuan Ayat (1) butir c ini adalah untuk lebih memastikan bahwa penghadap tidak dengan mudah menyangkal tanda tangannya yang tertera dalam minuta akta, selanjutnya nara sumber tersebut menjelaskan bahwa sidik jari tersebut tidak dimaksudkan sebagai pengganti (surrogate) dari tanda tangan penghadap, ketentuan Ayat (1) butir c tidak menyebutkan secara tegas (1) kapan sidik jari tersebut dibubuhkan pada kertas yang akan dilekatkan pada minuta tersebut, harusnya sesuai dengan tujuan hukum dari adanya ketentuan tersebut untuk memperkuat pembuktian maka seharusnya pelekatan kertas yang memuat sidik jari dilakukan sewaktu penandatanganan akta, (2) sidik jari dari jari tangan yang manakah, dan beberapa jari? Penjelasan dari bagian dactloscopy Kemenkumham, cukup jempol jari tangan kanan atau tangan kiri (jika masih ada masalah dengan jempol jari kanan).

2. Mengenai surat wasiat di bawah tangan, sesuai dengan Pasal 16 Ayat (1), yang menyatakan bahwa membacakan akta di hadapan penghadap dengan dihadiri oleh paling sedikit 2 (dua) orang saksi, atau 4 (empat) orang saksi khusus untuk pembuatan akta wasiat di bawah tangan dan ditandatangani pada saat itu juga oleh penghadap, saksi, dan notaris maka terhadap hal ini harus jelas dibedakan mengenai pengertian 
wasiat. Wasiat olografis seluruhnya harus ditulis sendiri oleh pewasiat dan ditandatangani, serta diserahkan secara terbuka atau tertutup untuk disimpan notaris. Wasiat olografis (olografische-testament) diatur dalam Pasal 932 BW. Setelah dibuat akta penyimpanan (akte van depot) atas wasiat olografis tersebut maka wasiat tersebut mempunyai kekuatan sebagai suatu wasiat umum yang dibuat di hadapan notaris, wasiat codicil atau wasiat dengan surat di bawah tangan seperti yang ditentukan dalam Pasal 935 BW, wasiat umum dengan akta notaris, dengan syarat akta ditanda tangani terlebih dahulu oleh pewasiat, notaris baru para saksi, wasiat tertutup atau rahasia, tidak harus ditulis sendiri oleh pewasiat, tapi pewasiat harus menandatanganinya sendiri.

3. Bahasa akta notaris yang dijelaskan dalam Pasal 43. Menurut hemat penulis akta yang dibuat dalam bahasa Indonesia berdasarkan pasal ini berarti akta yang dibuat dalam bahasa asing harus pula dibuat dalam bahasa Indonesia, berarti dengan demkian tidak cukup dengan terjemahan ke dalam Bahasa Indonesia, tapi harus dibuat akta dalam 2 (dua) bahasa (bilingual). Sehingga dengan demikian telah sesuai pula dengan ketentuan Pasal 31 Undang-Undang Nomor 24 Tahun 2009 tentang Bendera, Bahasa dan Lambang Negara, Serta Lagu Kebangsaan.

4. Mengenai akta berita acara pembetulan salah tulis/ketik, seperti yang diatur di dalam Pasal 51. Pada Pasal 51 ini ada perbandingan redaksi antara Pasal 51 Ayat (2) UUJN dengan Pasal 51 Ayat
(2) perubahan UUJN. Dalam Perubahan UUJN mensyaratkan adanya kehadiran penghadap, saksi dan notaris untuk membuat pembetulan tersebut yang dituangkan dalam akta berita acara dan memberi catatan mengenai hal tersebut dalam minuta akta (yang diperbaiki) dengan menyebutkan nomor dan tanggal akta berita acara pembetulan. Sementara itu, dalam Pasal 15Ayat (2) UUJN tidak mensyaratkan kehadiran penghadap tersebut, cukup notaris di hadapan para saksi membuat akta berita acara tentang pembetulan atas salah tulis/ ketik yang terdapat pada minutanya. Tentunya kesalahan tulis atau kesalahan ketik tersebut, terbatas pada kesalahan tulis/ketik yang terang benderang dan bukan atas kesalahan tulis/ketik yang kedua-duanya mempunyai arti yang samar.

\section{Penutup}

Judicial review pada dasarnya adalah untuk mengawal suatu undang-undang sampai pada tujuan hukumnya, yakni kepastian, keadilan dan kemanfaatan yang berujung pada kesejahteraaan. Tercatat 3 kali dilakukan judicial review pada UUJN. Namun, hanya satu yang dikabulkan oleh MK, yakni judicial review mengenai Pasal 66 pada Undang-Undang Nomor 30 Tahun 2004 tentang Undang-Undang Jabatan Notaris. Tentu saja judicial review ini memiliki implikasi terhadap perkembangan pengaturan jabatan notaris di Indonesia.

Implikasi pada pemanggilan notaris dalam penegakan hukum oleh penegak hukum tidak perlu lagi atas seizin dari MPD, karena kewenangannya telah dibatalkan oleh MK. Keputusan MK ini mendorong terbentuknya undang-undang baru menggantikan undang- 
undang lama, yaitu Undang-Undang Nomor 2 Tahun 2014 tentang Perubahan UndangUndang Nomor 30 Tahun 2004 tentang Undang-Undang Jabatan Notaris. Melalui perubahan UUJN ini ternyata menghidupkan kembali Pasal 66 yang sebelumnya telah di judicial review yang berakibat pemanggilan notaris harus melalui organisasi. Meskipun UUJN ini merupakan perubahan dari UUJN yang lama, namun kelemahan tetap ditemukan dalam perubahan UUJN ini. Kelemahan tersebut didasari faktor penyusunannya. Di dalam perubahan UUJN yang diundangkan di tahun 2014, substansi atau materinya disusun dan dipersiapkan oleh pihak yang berada di luar pihak pelaku notariat, yang tidak mustahil mempunyai pandangan atau persepsi yang berbeda dengan pandangan notaris dalam beberapa masalah kenotariatan.

Terhadap gagasan politik hukum kenotariatan pasca perubahan UUJN maka penulis menawarkan gagasan perbaikan perubahan UUJN agar terciptanya kepastian hukum bagi jabatan notaris dalam menjalankan tugasnya termasuk juga melakukan perbaikan dalam hal frasa undang-undang agar kalimatkalimat dalam undang-undang tersebut tidak mengandung kekeliruan atau memiliki makna yang ambigu.

\section{Referensi}

Abdul Ghofur Anshori. 2009. Lembaga Kenotariatan Indonesia Perspektif Hukum dan Etika. Yogyakarta: UII Pers.

Aryani Witasari. MPD Buka Advokat Para Notaris Berdasarkan Undang-Undang No. 30 Tahun 2004 tentang Jabatan Notaris. Jurnal Hukum. Volume XXVII. Nomor 2. Desember 2012.

Charles Simabura. Peran Mahkamah Konstitusi Dalam Mewujudkan Demokrasi Ekonomi (Identifikasi
Putusan Pengujian Undang-Undang Terhadap UUD 1945). Jurnal Konstitusi. Volume 2. Nomor 1. September 2013.

Delfina Gusman. Problematika Dalam Pembentukan Peraturan PerundangUndangan di Indonesia. Jurnal Yustisia. Volume 19. Nomor 1. Tahun 2012.

Georg Vanberg. 2005. The Politics of Contitusional Review in Germany. Inggris: Cambridge University Press.

Guntur Iskandar. Kekuatan Pembuktian Akta di bawah Tangan yang disahkan dan dibukukan Oleh Notaris. Jurnal Yustisia. Volume 22. Nomor 1. Juni 2015.

Habib Adjie. 2011. Majelis Pengawas Notaris Sebagai Pejabat Tata Usaha Negara. Bandung: Reflika Aditama.

J.E. Sahetapy. 2007. Yang Memberi Teladan dan Menjaga Nurani Hukum dan Politik. Jakarta: Komisi hukum Nasional RI.

Laurensius Arliman S. 2015. Notaris dan Penegakan Hukum oleh Hakim. Jogjakarta: Budi Mulia.

Musri Nauli. Pandangan Konstitusi Terhadap Notaris (Studi Kasus Putusan MK Terhadap Notaris). Jurnal Kenotariatan. Universitas Jambi. 2014.

Peter Mahmud Marzuki. 2009. Pengantar Ilmu Hukum. cetakan kedua. Jakarta: Kencana.

Rahmad Hendra. Tanggung Jawab Notaris Terhadap Akta Otentik yang Penghadapnya Mempergunakan Identitas Palsu di Kota Pekanbaru. Jurnal IImu Hukum. Volume. 3. Nomor 1.

Siti Sundari Rangkuti. 2008. Dinamika Perkembangan Hukum Tata Negara dan Hukum Lingkungan. Surabaya: Airlangga University Press. 
Unan Pribadi. Tinjauan Kritis Tentang Pengaturan Kembali Substansi Ketentuan Pasal 66 Ayat (1) UndangUndang Nomor 30 Tahun 2004 tentang Jabatan Notaris yang Sudah dinyatakan Tidak Mempunyai Kekuatan Hukum Mengikat oleh Mahkamah Konstitusi. Jurnal Legislasi Indonesia. Volume 11 Nomor 2. Juni 2014.

Widhi Handoko. 2014. Matrik Perubahan UUJN- Undang-Undang Nomor 30
Tahun 2004 Sebelum dan Setelah Revisi Tanggal 17 Desember 2013. Semarang: Universitas Dipenogoro.

Yuliandri. Membentuk Undang-Undang Berkelanjutan. Jurnal Konstitusi. Volume II. Nomor 2. November 2009. Zulheriyanto. Pembaharuan Surat Kuasa Membebankan Hak Tanggungan (SKMHT) Dalam Pemasangan Hak Tanggungan. Jurnal Minuta. Volume 1. Nomor 1. Agustus 2013. 